\title{
Blackhood as a category in contemporary discourses on Black Studies: An existentialist philosophical defence
}

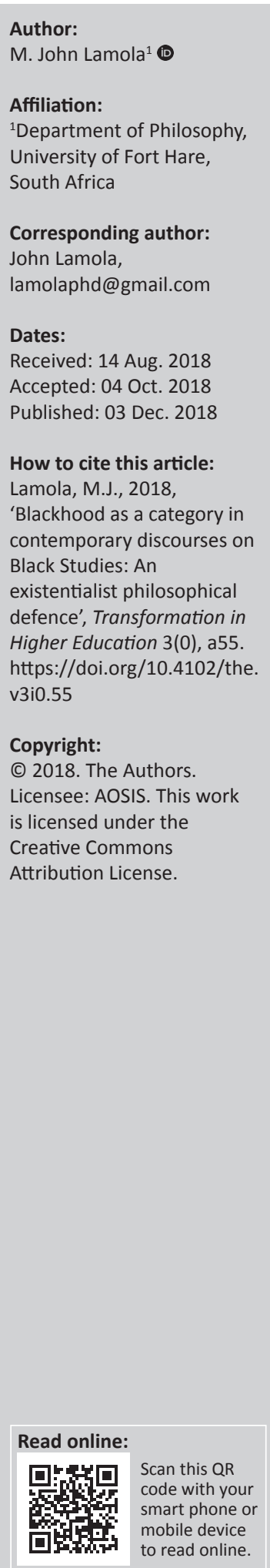

Background: An era and academic milieu that clamour at post-racialist and globalist theoretical frameworks juxtaposed with evidence of growing anti-black dehumanizing racism, and the persistence of psycho-social alienation of black learners in multi-racial educational institutions.

Aim: To engage in a critical philosophical-phenomenological and political review of the experience of being-black-in-the-world as a factor that justifies the establishment and maintenance of Black Studies programmes. The article seeks to contribute to the debate on the vagaries accompanying the institutionalisation of culturo-epistemic exclusive spaces for socially suppressed selfhoods in a postmodern academy.

Setting: Racialised social environments as affecting Higher Education, with post-apartheid South Africa as a case.

Methods: Existential Philosophy, Black Consciousness and Paulo Freire's philosophy of education.

Results: The category of blackness as derived from a Fanonian existential phenomenology and Steve Biko's perspective, contrasted against Achille Mbembe's semiological-hermeneutic and cosmopolitan treatment of blackness, is an existential-ontological reality that should function as a cardinal category in educational planning, justifying specialised learning and knowledgeexchange spaces for the re-humanisation of black existence.

Conclusion: The experience of black existential reality, conceived from blackhood as an external recognition and an internally self-negotiated consciousness within the social immanence of whiteness, justifies the institutionalisation of learning spaces and programmes that are aimed at nurturing antiracist black self-realisation, namely Black Studies.

\section{Introduction}

We are engulfed by a Zeitgeist (The spirit of the time) of globalisation and globalism. Our thinking is dazzled with imaginaries ${ }^{1}$ the 'global community', 'global village' and the concomitant ideal of cosmopolitanism. We are ethically impelled to aspire for the social ontology of a cosmopolitarian Being, the 'world citizen' who is not 'colour conscious'. ${ }^{2}$

Writing in the year 2000 as a philosopher studying the impact of this fundamentally and rapidly changing world on discourses on race and colonialism, in his Our Heritage: The Past in the Present of African-American and African Existence, Tsenay Serequeberhan (2000) proclaimed:

We are, at the close of the twentieth century, at a point in time when the dominance of the universe of European singularity is being encompassed or engulfed by the multiverse of our shared humanity. The colonizer, self-deified imperial Europe, is dead! (p. 52)

Nearly 20 years since this proclamation of the death of the epistemic emperor, Europe and his Eurocentric universalism, and nearly 30 years since Appiahs' critique of African 'nativistic consciousness' in his In My Father's House: Africa in the Philosophy of Culture (1992:47-72), in this putative era of the global village and multiversalism, African modes of self-knowledge and expression are still battling for space in the mainline academy, including in universities on the African continent. Equally, the idealised global culture and ethic is proving to be laced with an ever-increasing Western paranoid nationalism, border politics, antiblack racism and the tendency to treat Africans as a surplus people. ${ }^{3}$

2.From the title of the book Colour Conscious: The Political Morality of Race (Appiah \& Gutmann 1996).

3.Images of black deaths in the Mediterranean sea, anti-African immigration into Europe; Hage's (2003) study of racism in Australia; police killings of black people in the USA; persistence of socio-economic discrimination against black livelihood in post-apartheid South Africa and so on 
With our minds, as black Africans, suffocating, we gasp and scream out with Amina Mama, who at a symposium organised by the Nordic Africa Institute under the theme Identity and Beyond: Rethinking Africanity, protested 'We are being asked to think "beyond identity", when for many of us identity remains a quest, something in-the-making' (Mama 2001:9). Emanating from this crisis and confusion, or rather in a quest to situate the dilemma of African existence in this self-reconstituting world, Appiah's post-racialism (1992) and cosmopolitanism (2007), together with Achille Mbembe's Afropolitanism and racial relativism, ${ }^{4}$ have gained prominence as the conceptual frameworks in tune with this Zeitgeist of a globalising world.

We are cautioned that to focus our academic research and teaching on matters African, and particularly to promote academic programmes that are specifically concerned with the condition of black people in this multiculturising and post-racialising world, is to indulge in a parochial social anthropology, racial essentialism and jingoistic race-based provincialism (see Eze 2014). In fidelity to this task, in a 2006 article titled 'On the Postcolony: A Brief Response to Critics', Mbembe (2006) laments the rise of anticolonial African postcolonial theory with these words:

By insisting too much on difference and alterity, this current of thought has lost sight of the weight of the fellow human (le semblable) without whom it is impossible to imagine an ethics of the neighbour, still less to envisage the possibility of a common world, of a common humanity. (p. 153)

The contradiction of an intellectual climate that is uncomfortable with ethnically specific knowledge bases and the unquenchable quest for a restorative African consciousness as expressed by Amina Mama is a grave challenge for the modern postcolonial African academy. Voices such as Austin Channing Brown's I'm Still Here: Black Dignity in a World Made for Whiteness (2018) haunt our postmodern consciousness.

When we later add references to the psycho-social experiences of black students in white-majority or whitedominated educational institutions, this article will explicatively argue that the task before the academy is more than pedagogic and may be beyond the theme of 'transforming higher education'. We aim to demonstrate that it is acutely existential, as this situation constitutes the epistemico-ontological antagonism of a people whose selfhood is constrained, oppressed. Our theme will develop as a thread linking education, freedom and the attainment of being-human as, incidentally, postulated by Paulo Freire in the Pedagogy of the Oppressed, where he writes that 'at all stages of their liberation, the oppressed must see themselves as women and men engaged in the ontological and historical vocation of becoming more fully human' ([1970]2005:65). Specifically, the task at hand is about the quality of the selfunderstanding that is gained through education, by persons

4.Mbembe, Critique of Reason (2017:11) 'In fact, race does not exist as a physical anthropological, or genetic fact. [ $t$ is] just a useful fiction, a phantasmagoric construction, or an ideological projection'. who happen to be encountered in terms that degrade their humanity as they happen to have a darker skin pigmentation or any of the biological traits that tend away from Europeanity. ${ }^{5}$

Therefore, besides the theoretical embroilment into the meanings of various nuances of racial consciousness that we will unavoidably have to delve into, a consideration of the academic condition of black people drives us to advocate that the healing, nurturing and unleashing of black African excellence requires institutional spaces that are organised for and focused on the complications and possibilities of livedblack-experience-in-a-white-racist-world. We deduce the philosophical import of the socio-pedagogical complications that justify, for instance, the production of resource tools such as Moore, Marguerite and Penick-Park's (2018) The Guide for White Women Who Teach Black Boys.

In his contribution to What White Looks Like: African-American Philosophers on the Whiteness Question, Taylor (2004) helpfully distils whiteness, whiteliness and whitely thinking as racially discriminative and hegemonic social and epistemic practices (2004:229-230). This delineation discursively lifted the discourse on racial experience away from the biologicalmetaphysical plane to the hermeneutical-phenomenological level. It is noteworthy that the common thread to the meanings of all these designations of white social ontology is how the privileges and way of thinking that is taken for granted by white people is being routinised as representing what is 'normal' in a racialised world. In his study of racism in Australia, Gassan Hage demonstrably adds to Taylor's heuristic that the core element of Australia's colonial paranoia is a fear of a loss of Europeanness or whitenes, and of the lifestyle and privileges that are seen to emanate directly from that' (Hage 2003:49).

The congruence of whitelines as a commitment to and a rationalisation of the privileges that are self-appropriated and enjoyed by people of European descent, ${ }^{6}$ and whitenes as the idealised human lived experience, together with whitely thinking as the mainstream epistemology of the modern world, adumbrate the frustration and subjugation of black being as a lived experience. This includes a suppression and an erasure of expressions of knowledge production, which eventuates in constricting possibilities of selfknowledge. This, existentialist phenomenologists will say, is to deny the very Being, the being-in-the-world (Dasein), of black people. According to Martin Heidegger, human being is facilitated through enabled cognitive capacity; Existen $z^{7}$ is enabled by understanding (Verstehen) (Heidegger 1962:67). And according to Jean-Paul Sartre, the authentic self-creating

5.On Europeanism and identity challenges of defining 'a European' since the fall of the Berlin Wall see Patterson 1993, in National Identity and Europe.

6.Whiteliness tends to involve a commitment to the centrality of white people and their perspectives ... The way they see the world just is the way the world is, and the way they get around in the world just is the right way to get around. (Taylor way they

7.Contrasted with merely to 'live' which implies only survival; to 'exist', as used here by Heidegger, implies a deeper involvement in the process of 'becoming'. It means to 'stand out' from and against the what is. 
person, the 'For-itself', is a result of an intentional and selfdependent consciousness (Sartre 1992:541).

A consideration of the hegemonic power of whiteness and whiteliness against the quest for the redemption (renaissance?) of the black African Self in the neo-colonial juncture leads to the view that, left to itself, the mainstream whitely hegemonic academy is at best indifferent and at worst inimical to the cause of enriching black existential reality. To expect this academy to recognise black humanity is one thing; to expect it, as a bastion of whiteliness, to promote the black African Self borders on the absurd, as noted at least from Hage's definition of the modus vivendi of whiteness in Australia. In her 'How Do I Live in This Strange Place' (meaning as a white person in post-apartheid South Africa), Vice (2010) in a widely reviewed paper, after cautioning that she is not proposing 'a discipline called whiteness studies' (p. 324), suggested that white people must 'minimize our whiteliness' (p. 334) by going quiet (silent) on the consequences of their 'unavoidable whiteness', their being intractably embedded into a world of historical privileges (p. 335). Freire (2005), thus, recorded the obvious:

[T] he pedagogy of the oppressed cannot be developed or practiced by the oppressors. It would be a contradiction in terms if the oppressors not only defended but actually implemented a liberating education. (p. 54).

Against this dehumanising reality of whiteness and its whiteliness, we introduce blackhood as a countervailing recognition of black selfhood that is posited to frustrate the operationalisation of whiteness, specifically in the educational arena. Blackhood, we aim to demonstrate, is an appreciation of blackness as a phenomenon vested with socio-historical ramifications. Principally, it is an understanding of the psycho-epistemic and political obligations emanating from these ramifications without necessarily claiming a biological essence for this blackness. It is about the experience of being black in a hegemonic white racist world and the meaning(s) of this experience. It has nothing to do with racial essentialism. As we explain further on, it is about the political realism and phenomenological challenge of authentic existence, the existentiality of persons we recognise as black. Blackhood, therefore, is not a metaphysical but an existentialist-phenomenological construct. This will become clearer as we later differentiate it from Mbembe's abstract semiotic-hermeneutic treatment of blackness in his Critique of Black Reason (2017). Thus refined, we will argue that blackhood must be the cardinal (cardinale, 'guiding rule') category in justifying, designing and maintaining Black Studies programmes.

Based on the foregoing, we make a distinction between Black Studies and African Studies. Whilst African Studies is an 'area study' about Africa, Black Studies, as our article aims to demonstrate, is a socio-ontologically delimited field of research, engagement and learning that is seized with questions arising from the past and present experiences of being-black-in-a-white-world. Black Studies thus incorporates African Studies only in respect of those instances and aspects when it is studies by Africans about Africa, in other words, about themselves (see Mazama 2001). The correlative of African Studies is the burgeoning field of European Studies, despite the fact that from our perspective, in the main, the structure of our education in neocolonial Africa is simply European Studies. Our history major graduates know more about the history of Europe and next to nothing about the history of Africa.

We proceed by first establishing the historico-political context and background against which our argument for Black Studies is derived. Then, as a first step into the theoretical disputations of our disquisition, we review aspects of Mbembe's Critique of Black Reason (2017), drawing out the implications of the thesis of this treatise on the merits or otherwise of our argument for Black Studies. As we elaborate on the gist of our proposition, we grapple with the meaning of blackhood against the shadow of the prevalent postracialist cosmopolitarian critique of race-based thinking. This constitutes our leitmotif and flows into the concluding section of the article.

\section{Political and historical context}

Although a majority of countries in continental Africa are not as racially heterogeneous as South Africa and do not have the immediate black-white problem that South Africa is emblematic of, the template of our analysis and argument, whilst informed by South Africa, is derived from the view of whiteness and the challenge of blackhood as a globally manifesting phenomenon. We maintain that every contemporary black African is not only susceptible to the objectifying Euro-white gaze but that she or he is a subject of the grand narrative that holds black people in general as $a$ priori 'still uncivilised' or 'still developing'. At the conclusion of this article, it will appear as an awkward curiosity that whilst it is estimated that in the USA there are more than 100 Black Studies degree programmes offered at a variety of universities and colleges (Rojas 2007:10), there is a near paucity of such programmes in continental Africa.

Our basic argument that the black 'human condition' (Arendt 1958) justifies the promotion of institutional academic programmes that are focused on this state of 'blackness' recalls the agitation and efforts of W.E.B. du Bois at the dawn of the 20th century. He monumentally decided that the vehicle for the revalorisation of the de-valorised black selfhood would be through his founding, in 1897, of the American Negro Academy. This was borne out of his discernment on how a black person in a white racist society lived in a 'world which yields him no true self-consciousness, but only lets him see himself through the revelation of the other world' (Du Bois [1903]1997:38). The consequence of this was a 'double consciousness', which he explicated thus:

It is a peculiar sensation, this double-consciousness, this sense of always looking at one's self through the eyes of others, of measuring one's soul by the tape of a world that looks on in amused contempt and pity ... (Du Bois [1903]1997:38). 
Afforded no true self-consciousness, which is the existential condition of being, and with a cultivated (by the mainstream education system ${ }^{8}$ ) double consciousness in a white racist country, black Americans needed to find educational means of crafting their own singular black consciousness and to force the world (Social Sciences) to accept that black is normal.

Du Bois's approach, of course, we may be cautioned, belongs to a dead era; it belongs to the museum of African history, according to Appiah and Mbembe (see Serequeberhan 2000:22-23). It is therefore noteworthy that because of pressures from this race-sensitive spirit of the times, there is in the USA an incipient shying away from the term Black Studies, in preference of the 'post-racial' African-American Studies. In addition, criticisms of the quality of Black Studies programmes, and the charge that they are ghettoising black intellection, abound (see Brock, Nix-Stevenson \& Miller 2016). Notwithstanding, the publication of The African American Studies Reader (2007), an 850-page anthology with 73 essays edited by Nathaniel Norment Jr, stands as a compelling testimony that the question of the reality of black educational experience and its ontological imperatives is a veritable scientific concern.

In a recent South African research paper in Transforming Higher Education entitled 'Social identities and racial integration in historically white universities: A literature review of the experiences of black students', Bazana and Mogotsi (2017) expose how 'institutional cultures in historically white universities alienate and exclude black students' identities' (2017:1). They found that 'these students' sense of social identity, which includes culture, heritage, language and traditions, and consequently selfesteem and self-concept, is altered in these institutions' (Bazana \& Mogotsi 2017:1). Writing as psychologists, they lay bare, empirically, the trauma and sense of non-belonging of these black students in these obstinately white (whitely?) university spaces (2017:4). In their conclusion they endorse Steve Biko's argument and cautionary warning against racial integration and non-racial alliances that incorporate the uncured racial complexes of white superiority and black inferiority (see Biko 1970a:20-28).

At the same time, The Black Scholar: Journal of Black Studies and Research published a special focus issue on South Africa. According to the editors, 'the issue [was] meant to inaugurate a conversation on what the place of Black Studies and studies of blackness have in post-apartheid and post-Mandela South Africa [sic]' (Modisane, Collis-Buthelezi \& Ouma 2017:4). In a lead article by one of the guest editors, CollisButhelezi (2017), entitled 'The Case for Black Studies in South Africa', it is highlighted that one of the blind spots of the post-Mandela era had been that to talk openly and frankly about race was 'extremely dangerous' until the recent upsurge in social media reports of racial incidents and the spate of 'service delivery' protests owing to the continuation of racially structured economic inequalities (Collis-Buthelezi 8.See The guide to white women who teach black boys.
2017:18). This new reality check, it is reasoned, requires structured academic discourse such as that possible in and around a Black Studies programme.

None of the articles in the special issue (Modisane et al.) addresses the philosophical-psychical issues we probe in this article. Nevertheless, they represent a useful historical and political background to our philosophical reflection. Incorporating the results of Bazana and Mogotsi (2017) and their reference to Biko, we believe that, at the least, elective course programmes that are focused on reversing the educational lens in a direction that affirms black pride and self-assertion should be offered to enable black learners to re-enter the multicultural, albeit Eurocentric, educational system with an epistemic attitude that is imbued with their black consciousness and Afrocentric perspectives that they can articulate with confidence. Other modalities of Black Studies that could be pursued within this spectrum will be left for the conclusion of this disquisition.

\section{Being a black person is a phenomenon of a capricious imagination?}

Two archetypes on the conceptions of blackness in African scholarship are of relevance to us: those of Mbembe and Appiah. In the interests of brevity, we shall not return to Appiah, for his overly autobiographical cosmopolitanism adds little to the specific intricacies of philosophising about black ontology.

Mbembe is poignantly relevant to the discourse that constitutes Black Studies. In Critique of Black Reason (2017) he sets out in what promises to be a distillation of contemporary insights on racism from his analysis of the history of the racialisation of black skin. 'The Black Man', he writes, 'is the only human in the modern order whose skin has been transformed into the form and spirit of merchandise - the living crypt of capitalism' (2017:6). From there his reflective analysis devolves into a conception of this history of the racialisation and instrumentalisation of the African as being merely le imaginaire, that is, an act of the imagination and invention of blackness by the European colonial discourse on Africa. The apogee of this postulation is that:

$[I f]$ there is one space in which the imaginary relationship and the economy of fiction undergirding it existed in the most brutal, distinct, and obvious form, it is in the sign that we call Blackness and as it ricochet [sic], in the seeming outer zone that we call Africa, both of which are fated to be not common nouns, or even pronouns, but rather mere indicators of an absence of achievement. (Mbembe 2017:12; [author's own emphasis])

Blackness, according to Mbembe, is a semiotic sign, a mere indicator of something else. The term 'black people', lé Négre, a word of Iberian origin, he explains, was captured and deployed by European slave merchants and colonists for purposes of subjection and exploitation of the 'Black Man' (p. 20). Blackness is an opportunistic and neurotic invention 
of the European racialising mind (p. 113). It should therefore be inferred, he insists, that 'blackness does not exist as such. It is constantly produced' (p. 18). Consequently:

the term [blackness] first designates not a significant reality but a field - or better yet, a coating - of nonsense and fantasies that the West (and other parts of the World) have woven and in which it clothed people of African origin long before they were caught in the snares of capitalism as it emerged in the fifteen and sixteenth centuries. (Mbembe 2017:39)

He then categorically concludes that 'we uphold the idea that neither blackness nor race has ever been fixed ... they have, on the contrary, always belonged to a chain of open-ended signifiers' (p. 6). For completion, he would hasten to: 'add that whiteness in turn was, in many ways, a fantasy produced by the European imagination, one that the West has worked hard to naturalize and universalize' (p. 43).

Race for Mbembe (2017) is a fiction of a once-upon-a-time colonial conspiracy that turned peoples found in Africa into objects of exploitation:

For it to operate as affect, impulse and a speculum, race must become image, form surface, figure, and - especially - a structure of the imagination ... it is an operation of the imagination, the site of an encounter with the shadows and hidden zones of the unconscious. (p. 32)

Upon closer analysis it becomes apparent that Mbembe's conceptualisation of blackness (he methodically capitalises the word to denote that it is an abstract construct) is ultimately driven by a commitment to de-essentialise being black, that is, the concept of race in its generality. In the process, however, this blackness is turned into a hermeneutic of some contemporary social-historical phenomenon. He claims that:

Across early capitalism, the term 'Black' referred only to the condition imposed on peoples of African origin ... Now, for the first time in human history, the term 'Black' has been generalized. This new fungibility, this solubility, institutionalized as a new norm of existence and expanded to the entire planet, is what I call the Becoming Black of the world. (Mbembe 2017: 5, 6)

Blackness is now a norm of existence that applies to the entire planet, which is becoming black! This is tantamount to an erasure of black-lived experience as a verifiable social ontology of people recognised in today's world as 'black Africans'.

To further buttress his relativisation of blackness as blackness, he revels in narrating how during the Atlantic slave trade, not all black people in the New World were slaves. 'They served not only as servile labourers but also as ship's crewmen, explorers, officers, settlers, property owners, and, in some cases, freemen who owned slaves' (Mbembe 2017:15). So, blackness, in his argument, cannot be absolutised as a condition of suffering that solely emanates historically from European racial subjection. Human exploitation and violence are de-essentialised as behavioural traits that are not the monopoly of white people as a technique to denude the grievance of brutalisation that is inherent in the definition of black existence.
In the preface to the Wits University Press edition of the book, he volunteers the fact that his thoughts on blackness are formulated within his broader objective of the construction of the social ontology of Afropolitanism. This Afropolitanism is defined as pan-African and non-racial consciousness that rejects all pretensions to victimhood associated with the colonial past. This epistemically advocates an African consciousness that is open to the world and is briskly trading culture with the rest of the world. Ontologically, it aims for a supra-African consciousness that projects itself in the world without regard for the pain and humiliations of Africa of yesterday and today, living out the eschaton of a non-racial future. ${ }^{9}$

Blackness, according to Mbembe and those who agree with him (see Eze 2016), is only a representation in the sense of the semiological hermeneutics of Paul Ricoeur; ${ }^{10}$ it can therefore be socio-historically ephemeralised as a cosmopolitan Afropolitan ontology. In contradistinction, going beyond Fanon's exposition on the power of the gaze in the formulation of the consciousness of the Negro colonial subject, Biko would hold that socially grounded black self-affirmation and self-definition in the face of the denial of the black self by the white racist environment is crucial. It is an ontological imperative towards freedom. He declared:

Merely by describing yourself as black you have started on a road towards freedom, you have committed yourself to fight against all forces that seek to use your blackness as a stamp that marks you out as a submissive being. (1971:52)

To deny, wish away and erase blackness is to pull the carpet out from under the march of the black-aggrieved towards self-rehumanisation.

\section{Black reason and Black Studies}

All theoretical notions, definitions and debates on blackness considered, given the critical pedagogical and revolutionary task at hand, we would assert with Freire (2005):

The central problem is this: How can the oppressed, as divided, ${ }^{11}$ unauthentic beings, participate in developing the pedagogy of their liberation? (p. 48)

Does the globalisitic semiotic hermeneutics with its Afropolitanism and the denial of the existential value of black experience draw or defend a space for the cultivation of an emancipatory educational system that addresses the current conditions as well as aspirations of black people in a world governed on the basis of white racial supremacy?

To address this question, one only needs to interrogate the title of Mbembe's treatise: 'Critique of Black Reason'. What is

g.For a definition and an apologia on Afropolitanism that supports Mbembe, see Eze (2016).

10.Mbembe elaborates this semiological theoretical framework in his On the Postcolony ([2001]2015, ad passim) and defends it in 'On the Colony: A Brief Response to Critics' (Mbembe 2006).

11.In Paolo Freire's ontological thesis, there is a divided 'existential duality of the oppressed, who are at the same time themselves and the oppressor whose image they have internalised' (2005:61). 
black reason? And why does it warrant a critique? Mbembe informs his readers that 'Black reason consists of voices, pronouncements, discourses, forms of knowledge, commentary, and non-sense, whose object is things or people "of African origin"' (2017:27). This definition, obviously, has consequences for the subject of our article. Mbembe does not stop there, though; he continues:

Black reason names not only a collection of discourses but also practices - the daily work that consists in inventing, telling, repeating, and creating variations on the formulas, texts, and rituals whose goals was to produce the Black Man as a racial subject and sight of savage exteriority, who was therefore set up for moral disqualification and practical instrumentalisation. (p. 28)

Stripped of its instrumentalist lamentations against what Europeans did to Africans at the start of the colonial era, Critique of Black Reason is a denunciation of the anticolonial intellectual heritage that informs the need for institutions such as Black Studies and even much of the current syllabi and agenda of African Studies. In fact, given Mbembe's abstractive rendition of black, the very title of the book has a deliberate derogatory ring. It is a parody of a 'coloured' reason. How can reason be black? In its purpose, the book is part of a campaign of what Chielozona Eze has pronounced as the mission of Afropolitanism in his Mbembe-praising article 'We Afripolitans' (Eze 2016), namely to 'disrupt' black thinking on race and identity and 'to rescue black scholarship from oppositional conceptions of identity' (Eze 2014:234).

Granted the requirement for scientific and philosophical critical scholarship, given the current milieu of contestations on race and transformation, as well as the historical power disequilibrium between white and black people, is it not disingenuous to point a critique onto the self-formulations of the disempowered historical victims of white racism? Does this not debilitate them at a juncture when what they sorely need is vitalisation of their struggle-to-be? Why a 'critique of black reason' wherein black reason is admittedly an anticolonial and antiracist discourse? Is it because its only $\sin$ is that it does not realise the colourless cosmopolitanism dreamed of by Mbembe and his school (see Appiah 2007; Appiah \& Gutmann 1996)? Has postcolonial scholarship exhausted its exploration and 'Critique of white racist reason'?

White reason is whiteliness, a systemic justification, obfuscation and silence on 'whiteness'. As an ideology of white supremacy that justifies the taking for granted of the whitely way of things, it has what is only a predatory relationship with blackness. This, as is now well known, stems from the synonymification of black people or blacks with Africa. Africa is a field of extraction for the European, both psycho-philosophically and economically. In its abjection, Africa props up the European's ego in his selfconception as the paragon of being-human. Africa's perpetual pauperisation through the manner in which her natural wealth continues to be exploited by forces of market liberalism has sealed her eternal dependency on external political sovereignties. Mutatis mutandis; as the whitely educational space is defined and delimited by whiteness and whiteliness, must black children consume white education-culture into eternity, whilst attempts at countervailing this academic whiteness are subjected to globalistic rationalisations that deny the reality of black existence and lampoon their intellection and emancipatory programme as 'Black Reason'?

\section{Being a black person as a social and existential imperative}

Black existentiality - the meanings reverberating from existing (understanding oneself) as a black person who is conscious of his or her blackness in a world that has formed views about persons with black skin - is the kernel of our disquisition. The latter reference to the import of black skin in defining black existentiality recalls Biko's (1971) definitive assertion that:

Black Consciousness is in essence the realisation by the black man of the need to rally together with his brothers around the cause of their oppression - the blackness of their skin - and to operate as a group to rid themselves of the shackles that bind them to perpetual servitude. (p. 53)

Biko's thinking was influenced by Frantz Fanon's grapple with the phenomenological existentialism of Jean-Paul Sartre, as well as Maurice Merleau-Ponty's phenomenology of embodied consciousness, within the hubris of the politics of the Négritude movement. The point of departure of this thinking is the appreciation of the relationship between the material experience of the human agent and the quality of her or his self-consciousness. For example, the following quotation from Merleau-Ponty's Phenomenology of Perception by Fanon is strategic:

For a being who has acquired consciousness of himself and of his body, who has attained to the dialectic of subject and object, the body is no longer a cause of the structure of consciousness, it has become an object of consciousness. (Fanon 1986:175)

Consciousness of the body is a legitimate ingredient of selfawareness.

Asserting this somatic reality of the black colonial subject in Black Skin, White Masks ([1952]1986), Fanon makes a countervailing reflection on Sartre's observations in AntiSemite and Jew on how the Jew is in fact a product of the mental representation of the anti-Semite. Sartre is quoted by Fanon:

They [the Jews] have allowed themselves to be poisoned by the stereotype that others have of them, and they live in fear that their acts will correspond to this stereotype ... We may say that their conduct is perpetually overdetermined from the inside. (Fanon 1986:87)

Fanon retorts: 'I am the slave not of the "idea" that others have of me but of my own appearance' (Fanon 1986:87). Being a black person is not merely an idea of the Othering subject or a representation of a capricious colonial mind. 
It is a material reality of being, a facticity whose social ontology has to be self-negotiated.

Of vital importance, though, is that for Fanon, especially as articulated in his later The Wretched of the Earth (Fanon [1961]1991), this awareness and theoretic deployment of his somatic appearance was consistently conceptualised from an existential-phenomenological perspective. He does not engage in the metaphysics or eugenics of 'the black skin'; equally, he does not reduce the lived reality of the black colonial subject ('the Negro'), his being-in-the-world, into some hermeneutic sign, as Mbembe would. From his very early encounter with the Négritude movement, he was never obsessed with blackness, for blackness sake, but with the lived political actuality of black existence as deformed by colonialism. This he monumentally outlined in Chapter 5 of Black Skin, White Mask, 'The Fact of Blackness' (Fanon [1961]1991: 82-108; see also Serequeberhan 2000:1-12). Following this Fanonian existential phenomenological thinking, Biko, whilst holding to what we quoted earlier on black skin as the cause of oppression, would thus assert that ' $[b]$ eing black is not a matter of pigmentation - being black is a reflection of a mental attitude' (1971:52).

This politically inspired understanding of how skin colour and racialism are experienced led to Fanon's agonised and revolutionary inclusivity of the very last sentence in The Wretched of the Earth: 'For Europe, for ourselves, and for humanity, comrades, we must make a new skin, develop a new thinking, and try to set afoot a new human being' (Fanon [1961]1991:315). ${ }^{12}$ The same mental disposition is resonated in the conclusion of Biko's (1973) analysis of the nature of the racial structures of apartheid South Africa in his essay 'Black Consciousness and the Quest for True Humanity':

We have set out on a quest for true humanity, and somewhere on the distant horizon we can see the glittering prize. Let us march forth with courage and determination, drawing strength from our common plight and our brotherhood. In time we shall be in a position to bestow upon South Africa the greatest gift possible - a more human face. (p. 108; see also Biko 1970a:27)

\section{Blackhood and the Self}

Our frequent references to existence, black existence, will need to be understood within the context of what we will call 'existentiality' as a function of human consciousness. Existentiality derives from both an 'inflectional' and 'exflectional' perspective, or interiority and exteriority, meaning that it denotes both intrasubjective consciousness as well as external institutional impositions on one's selfconsciousness, including the mere gaze of others. The given fact of existence as a black person, as a conscious being, is therefore about self-understanding (and self-negotiation) as a black person in constant confrontation with externally imposed definitions and categorisations of black personhood. It is in this sense that this self-negotiated selfhood is blackhood. The word 'self-negotiated' is here introduced to denote the intrasubjective (what Biko identified as the 12.We are using the translation utilised by Serequeberhan (2000:12). 'inward-looking process'; Biko 1970b:31) struggle to situate oneself against the generally hostile exteriority.

To the laboured reflections on the 'Other-as-a-look' by Sartre in Being and Nothingness, ${ }^{13}$ Fanon objected that this apparently harmless conception of alterity, the objectifying othering as formulated by the others' gaze, has different implications when applied to the encounter between the European coloniser and the Negro or colonised black people. For the black person, the framing Looker, the Other, is the little white boy with his mother, screaming, 'Look, a Negro! ... Mama the Negro's going to eat me up' (1986:84). The Negro is different, frightening, wicked, inferior, some exotic human-savage, an object of curious attention and fear. To deny that, well into the 21st century, black presence in a white world is still a magnet of a gaze that is a priori wrapped in either pity, spite, amused contempt or a fear that induces neutralisation is to be in 'Bad Faith', as Sartre would say. It is to lie to oneself. This affective phenomenon of pity, degradation and fear corroborates the hypostasis of blackhood, which becomes the antithesis of this racist affective complex.

This converse, or counter-push, is what Fanon claimed was absent from the Negroes, the Antilleans, he observed. They displayed no countervailing ontological resistance to the screaming little white boy as they were trapped in the 'zone of non-being' (1986:83). The ontological disequilibrium at play here, as in the master and slave dialectics, is the breakdown of blackhood. They had not self-negotiated the way they were viewed, encountered, recognised and treated by white racism; their selfhood was nullified.

Similar to the black folks of Fanon's Antilles in the neocolonial black African subject, we do not have a being-for-itself, a combatively self-creating self, as a given. Admittedly, we have the in-itself, a socio-material Being that is noted, observed, treated and related to by others. However, it is not the 'For-itself'. It is not the ens casui su [a being that causes itself], in the sense that Sartre would say that ' $[\mathrm{m}] \mathrm{m}$ is nothing else but that which he makes of himself' ([1946]2007:23). The ontology of a black African in a white racist world is quintessentially a being-through-others as well as being-for-others, until it is counter-self-negotiated. Others tell and teach her who she is, pricking and shaping her self-consciousness. She is not her own. She is in a 'zone of non-being'. Human being-in-the-world, if not actively engaged as a self-consciousness, is always a being-for-others, framed by ascriptions imposed by others as well as the ruling ideas and conventions of the day.

However, it gets more serious and critical than this. When linked to how learning and education involve basic cognitive selfunderstanding that makes Existenz ${ }^{14}$ and being-in-the-world

13.it is in its effort to choose itself as a personal self that the for-itself sustains in existence certain social and abstract characteristics which make of it man (or woman) each for-itself is responsible in its being for the existence of a human woman) ... each for-itself is responsible in its being for the existence of a human race ... for it is by choice that he [the for-itself] will apprehend the Other as The-Other-as-subject or as The-Other-as-object. Inasmuch as the Other is to him beneath the Other's look. (Sartre 1992:541)
ben itself as an object in the universe

14. Heidegger used the term Existenz with a peculiarity that signifies the transcendental nature ('supra-physis') of being-in-the-world (Heidegger 1987:67). 
possible (Heidegger's Dasein), as well as the intentional authenticity (being-for-itself) of Sartre, selfhood, from both a phenomenological and social perspective, is a reflection of the state of one's humanness. It is about the quality of consciousness as a reflection of the ontological quality of 'being human' that can be contrasted with the state of an animal that does not possess a capacity for 'self-consciousness'. This point is best elucidated by Freire (2005) in these words:

Unable to decide for themselves, unable to objectify either themselves or their activity, lacking objectives which they themselves have set, living 'submerged' in a world to which they can give no meaning, lacking a 'tomorrow' and a 'today' because they exist in an overwhelming present, animals are ahistorical ... In contrast, the people - aware of their activity and the world in which they are situated, acting in function of the objectives which they propose, having the seat of their decisions located in themselves and in their relations with the world and with others, infusing the world with their creative presence by means of the transformation they effect upon it - unlike animals, not only live but exist; and their existence is historical ... humans exist in a world which they are constantly re-creating and transforming. (pp. 98, 99 [author's own emphasis])

Are we human? Human phenomenological ontology, the ever-present danger of dehumanisation in a racialistically dehumanising world, demands black consciousness. This self-awareness of the meaning of being black, demands a nurtured positive cognition and learning that affirms and enriches one's sense of being black. Within the immanence of whiteness, this justifies spaces for learning and intellection as black people. It is only by owning and controlling their self-learning and education that black people can recover, maintain and defend their humanity. It is only through teaching herself, about herself, in her own space, and at her own pace, that a postcolonial black subject would attain the state of ens casui sui, 'a being that causes itself' and transforms its world.

Justifying this exclusive pedagogical space for black selfrealisation, Biko (1973), incorporating Freire's connection of pedagogy with freedom, explained:

On his own, therefore, the black man wishes to explore his surroundings and test his possibilities - in other words to make his freedom real by whatever means he deems fit. At the heart of this thinking is a realisation by blacks that the most potent weapon in the hands of the oppressor is the mind of the oppressed ... if one's mind is so manipulated by the oppressor as to make the oppressed believe that he is a liability to the white man, then there will be nothing the oppressed can do to scare his powerful masters. (pp. 101-102)

Biko's explication that is infused with the motif and goal of freedom, especially freedom of the mind (consciousness) as the very purpose of this exclusive pedagogical space, addresses the possible charge that the last statement in our previous paragraph sounds like a Verwoerdian philosophy of separate development. The goal of apartheid's segregation in education was inferiorisation and subjugation; the goal of the Black Studies programmes proposed here is for the black self-realisation that breaks the fetters of the black inferiority complex, denies the racial supremacist of a black inferiority complex that props him up, thus leading to freedom of both from false consciousness, pointing to a South Africa with 'a more human face', (Biko 1973:108), a 'country where colour will not serve to put a man in a box' (Biko 1970a:27).

\section{Blackhood for Black Studies}

Selfhood, we can now conclude, is the self pre-reflexively understanding and situating itself within time and place as human being in relation with others; it is situated selfawareness. It is the self, the ego, in the world. As such it reveals itself and can be observed and experienced or related to as an expression of an embodied self. It is an inert state that is only given a standing by the meaning we imbue in it, through recognition (and miscognition). Our disquisition has been about how black selfhood, the givenness of 'being black', reveals itself to 'us', is received and manifests in the world, that is, is given meaning, as blackhood. It is in this vein that Fanon in Black Skin, White Mask wrote of 'Negrohood' (1986:153) and deployed the following statement from Hegel's Phenomenology of Mind:

Self-consciousness exists in itself and for itself, in that and by the fact that it exists for another self-consciousness; that is to say, it is only by being acknowledged or recognized. (in Fanon 1986:168)

We are black because, unavoidably, so we are recognised. blackness therefore matters. It is not some historical imaginary propounded by colonising Europeans, as Mbembe opines.

Blackhood is about the social (recognition) ontology of being African and black in a world that is conscious of, or 'hails back' to, the existence or phenomenon of black bodies (Mearlau-Ponty). As such, blackness (the qualia) as a selfrevealing reality has to be conceived of as a component and an expression of Being as well as a historical reality. Blackness is the given, like a rock or a chair; blackhood is blackness as it appears to the mind laden with meaning, an object-as-intended. Blackhood is consciousness of blackness as it manifests with its epistemic (to the black, self-negotiating, knowing-subject) and socio-political ramifications (to the recognising-Other). It is only coterminous with selfhood to the degree that the self objectified in the world is always recognised, be it negatively or positively.

Black Consciousness, on the other hand, is the name of the internal, intrasubjective process. It is the self reflectively affirming itself, negotiating and negating the malicious externally imposed distortions, misrecognitions, of the black self (blackhood!) by others. It is the defence mechanism of blackhood. It is an assertive self-realisation, an 'attitude of mind' (Biko1973:101), that intentionally re-creates, antithetically, black selfhood. Blackhood, as a positive self-recognition of blackness, is constructed through Black Consciousness.

The matter of blackhood, therefore, relates to both 'existentiality', as a philosophical-ontological category, and 'existential reality', as a socio-political category. Existentiality 
raises the ontological question, 'How to be black in a white racist world that denies or proscribes the humanity of black bodies?', and existential reality is about the question, 'How do black people live in this racialised world?'

From this phenomenological perspective, it is noted that the very demand for and existence of spaces that support the proper recognition (humanity) of the black self is a revolutionary act in itself. To question, to ask about Being (Seinsfrage - Heidegger) is to be. It is an expression of being 'ek-sistent', of 'standing out' from the world of mere things (Heidegger 1987:17-21). ${ }^{15}$ In the context of our academic challenge, this 'standing out' involves grabbing opportunities for possibilities to 'come into consciousness' (Biko). Black Studies, or structured black-themed spaces, will ensure that even within the immanent and stifling mainstream whiteness, black existentiality resolves itself as a threatenedbut-defiant existence, an ontology of struggle, a combative ontology. A space in which we can 'write what [we] like'16 and have 'Frank Talk'17 without the censoring master peering over our shoulders. The white brothers and sisters can then tiptoe around, as Sartre dramatically advises in the preface to Fanon's The Wretched of the Earth:

Europeans, you must open this book and enter into it. After few steps in the darkness you will see strangers gathered around a fire; come close, and listen, for they are talking of the destiny they will mete out to your trading posts and mercenaries who defend them. They will see you, perhaps, but they will go on talking among themselves, without even lowering their voices. (Fanon [1961]1991:11)

\section{Acknowledgements}

The original draft of this article was presented at the 4th International Symposium of the Dakar Institute of African Studies, Senegal July 06-07, 2018 'Bridging the gap: Black Studies across social, geographical, epistemic, and linguistic lines'. The author acknowledges with gratitude the influence of the critical engagement of the participants on the article.

\section{Competing interests}

The author declares that he has no financial or personal relationships that may have inappropriately influenced him in writing this article.

\section{References}

Appiah, K.A., 1992, In my father's house: Africa in the philosophy of culture, Oxford University Press, Oxford.

Appiah, K.A. \& Gutmann, A., 1996, Colour conscious: The political morality of race, Princeton University Press, Princeton.

Appiah, K.A., 2007, Cosmopolitanism: Ethics in a world of strangers, Norton, New York.

15.It is sadly ironic, as raised by one peer reviewer, that our dissertation has to use what Heidegger had intended for the revolutionary Being of Nazi Germany. On this, we take solace in Slavoj Žižek's absoluter Gegenstoss [absolute recoil] - what the enemy had meant for our ill has turned to our good! (Zižek 2014:117-147).

16.Title of Biko's column (I Write What I Like) in the South African Students Organisation (SASO) journal, now the title of an anthology of his essays (edited by Stubbs [1978]2004).

17.The pseudonym Steve Biko used for his articles published in the SASO student press.
Arendt, H., 1958, The human condition, University of Chicago Press, Chicago, IL.

Bazana, S. \& Mogotsi, O.P., 2017, 'Social identities and racial integration in historically white universities: A literature review of the experiences of black students', Transformation in Higher Education 2, a25. https://doi.org/10.4102/the.v2i0.25

Biko, S., 1970a, 'Black souls in white skins?', in A. Stubbs (ed.), 2004, I write what I like, pp. 20-28, Picador, Johannesburg.

Biko, S., 1970b, 'We blacks', in A. Stubbs (ed.), 2004, I write what I like, pp. 29-35, Picador, Johannesburg.

Biko, S., 1971, 'The definition of black consciousness', in A. Stubbs (ed.), 2004, I write what I like, pp. 52-57, Picador, Johannesburg.

Biko, S., 1973, 'Black consciousness and the quest for a true humanity', in A. Stubbs (ed.), 2004, I write what I like, pp. 96-108, Picador, Johannesburg.

Brock, R., Nix-Stevenson, D. \& Miller, P.C. (eds.), 2016, The critical black studies reader, Peter Lang, Frankfurt.

Brown, A.C., 2018, I'm still here: Black dignity in a world made for whiteness, Convergent Books, New York.

Collis-Buthelezi, V.J., 2017, 'The case for black studies in South Africa', The Black Scholar: Journal of Black Studies and Research 47(2), 7-21. https://doi.org/10.10 80/00064246.2017.1295349

Du Bois, W.E.B., [1903]1997, The souls of black folk, D.W. Blight \& R. Gooding-Williams (eds.), Bedford Books, Boston, MA.

Eze, C., 2014, 'Rethinking African culture and identity: The Afropolitan model', Journal of African Cultural Studies 26(2), 234-247. https://doi.org/10.1080/13696815.20 14.894474

Eze, C., 2016, 'We Afripolitans', Journal of African Cultural Studies 28(1), 114-119. https://doi.org/10.1080/13696815.2015.1100065

Fanon, F., [1952]1986, Black skin, white masks, transl. C.L. Markmann, Pluto Press, Sidmouth.

Fanon, F., [1961]1991, The wretched of the earth, Evergreen edn., Grove Weidenfeld, New York.

Freire, P., [1970]2005, Pedagogy of the oppressed, transl. M.B. Ramos, The Continuum, New York

Hage, G., 2003, Against paranoid nationalism: Searching for hope in a shrinking society, The Merlin Press, London.

Heidegger, M., [1927]1962, Being and time, transl. J. Macquarie \& E Robinson, Blackwell, Oxford

Heidegger, M., 1987, An introduction to metaphysics, transl. R. Manheim, Yale University Press, New Haven, CT.

James, P. \& Steger, M.B. (eds.), 2010, Globalisation and culture, vol. 4, Sage Publications, London.

Mama, A., 2001, 'Challenging subjects: Gender and power in African contexts', in H. Melber (ed.), Identity and beyond: Rethinking Africanity, pp. 9-18, Nordiska Afrikainstitutet, Uppsala.

Mazama, A., 2001, 'The Afrocentric paradigm: Contours and definitions', Journal of Black Studies 31, 387-405. https://doi.org/10.1177/002193470103100401

Mbembe, A., 2006, 'On the colony: A brief response to critics', African Identities 4(2), 143-178. https://doi.org/10.1080/14725840600761096

Mbembe, A., [2001]2015, On the Postcolony, Wits University Press, Johannesburg.

Mbembe, A., 2017, Critique of black reason, transl. L. Dubois, Wits University Press, Johannesburg.

Modisane, L., Collis Buthelezi, V.J. \& Ouma, C. (eds.), 2017, 'Introduction: Black studies, South Africa, and the mythology of Mandela', The Black Scholar: Journal of Black Studies and Research 47(2), 2-6. https://doi.org/10.1080/00064246.201 7.1295348

Moore, E., Marguerite, A.M. \& Penick-Parks, W., 2018, The guide for white women who teach black boys, Corwin/Sage Publications, Thousand Oaks, CA.

Norment, N. Jr. (ed.), 2007, The African American studies reader, 2nd edn., Carolina Academic Press, Durham, Durham, NC.

Rojas, F., 2007, From black power to black studies: How a radical social movement became an academic discipline, John Hopkins University Press, Baltimore.

Patterson, R., 1993, 'Collective identity, television and Europe', in P. Drummond, R. Patterson \& J. Willis (eds.), National identity and Europe, pp. 1-7, BFI Publishing, London.

Sartre, J.-P., [1943]1992, Being and nothingness: An essay on phenomenological ontology, transl. H.E. Barnes, Routledge, London.

Sartre, J.-P., [1945]2007, Existentialism is a humanism, transl. C. Macomber, Yale University Press, New Haven, CT.

Serequeberhan, T., 2000, Our heritage: The past in the present of African-American and African existence, Rowman \& Littlefield, New York.

Stubbs, A. (ed), [1978]2004, I write what I like: Steve Biko, a Selection of his Writings, Picador, Johannesburg.

Taylor, P., 2004, 'Silence and sympathy: Dewey's whiteness', in G. Yancy (ed.), What white looks like: African-American philosophers on the whiteness question, $\mathrm{pp}$. 227-242, Routledge, New York.

Vice, S., 2010, 'How do I live in this strange place?', Journal of Social Philosophy 41(3), 323-342. https://doi.org/10.1111/j.1467-9833.2010.01496.x

Žižek, S., 2014, Absolute recoil: Towards a new foundation of dialectical materialism, Verso, London. 